УДК $378.147=111$

\title{
ПРИНЦИПИ ДОБОРУ МАТЕРІАЛІВ ДЛЯ НАВЧАННЯ КУРСАНТІВ ПЕНІТЕНЦАРНОЇ СЛУЖБИ АНГЛОМОВНОГО АУДІЮВАННЯ
}

\author{
Биконя О. П., Борисенко І. В., Іванишина В. П. \\ oksanabikonya@ukr.net, borisenko-irina@ukr.net, veraivanyshyna@ukr.net \\ Академія Державної пенітенціарної служби Украӥни \\ Дата надходження 15.03.2019 р. Рекомендовано до друку 15.05.2019 p.
}

\begin{abstract}
Анотація. У статті розглянуто питання добору навчального матеріалу для навчання майбутніх фахівців пенітенціарної служби англомовного аудіювання. Виокремлено принципи добору навчального матеріалу для навчання англомовного аудіювання. Зазначено, що матеріал дібрано на засадах професійно орієнтованого й ситуативно-функціонального підходів. У статті обгрунтовано такі принципи: тематичності; посильності й доступності; необхідності й достатності; вживаності; системності й послідовності; відповідності комунікативним потребам курсантів, їхному інтелектуальному рівню й інтересам; пізнавальної, соціокультурної та професійно практичної цінностей; автентичності.

Ключові слова: принципи, добір навчального матеріалу, англомовне аудіювання, курсанти пенітенціарної служби.
\end{abstract}

Быконя О. П., Борисенко И. В., Іванишина В. П. Принципы отбора учебных материалов для обучения курсантов пенитенциарной службы англоязычному аудированию

Аннотация. В статье рассмотрены вопросы отбора учебного материала для обучения англоязычному аудированию будущих специалистов пенитенциарной службы. Выделены принципы отбора учебного материала для обучения англоязычному аудированию. Отмечено, что материал отобран на основе профессионально ориентированного и ситуативно-функционального подходов. В статье обоснованы следующие принципы: тематичности; посильности и доступности; необходимости и достаточности; употребляемости; системности и последовательности; соответствия коммуникативным потребностям курсантов, их интеллектуальному уровню и интересам; познавательной, социокультурной и профессионально практической ценностей; аутентичности.

Ключевые слова: принципы, отбор учебного материала, англоязычное аудирование, курсанты пенитенциарной службы.

Bykonia O., Borysenko I., Ivanyshyna V. Principles of the materials selection for teaching penitentiary service cadets' English listening

Abstract. Introduction. The article focuses on the principles of the English material selection for teaching penitentiary service cadets' listening. Purpose. The article is to determine the principles of the English material selection for developing English competence in listening by cadets of the penitentiary service. Methods. The studies on methodological problems of teaching cadets' listening have been reviewed. It has been analysed the difficulties in developing English competence in listening by cadets of penitentiary service. Results. It is noted that the material has been chosen on the basis of professionally-oriented and situational-functional approaches. The article substantiates the following principles: thematic; sustainability and accessibility; necessity and sufficiency; usability; systemicity and consistency; accordance with cadets' communicative needs, their intellectual level and interests; cognitive, socio-cultural and professional-practical values; authenticity. Conclusion. To sum up, it has been determined that it is necessary to use these principles of the English material selection for teaching penitentiary service's cadets listening.

Key words: principles, selection of English material, listening, cadets of the penitentiary service.

Постановка проблеми. Вагомою в становленні майбутніх фахівців пенітенціарної служби $\epsilon$ освітня, навчальна й виховна робота. Зокрема, Академія Державної пенітенціарної служби державний, галузевий, заклад вищої освіти, що здійснює інноваційну освітню діяльність, пов'язану з наданням вищої освіти фахівцям пенітенціарної служби. Сьогодні випускники 
Академії мають відповідати багатьом критеріям, з-поміж яких - не тільки бути хорошим фахівцем обраної професії, але й всебічно розвиненою особою. Головними завданнями виховної й психологічної роботи $\epsilon$ організація громадянського й патріотичного виховання курсантів, проведення культурно-масових, фізкультурно-спортивних, науково-просвітницьких заходів; підтримка й розвиток соціальних ініціатив курсантів й організація їхньої зайнятості; вивчення проблем та організація психологічної підтримки тощо. 3 цією метою в Академії пенітенціарної служби проводиться робота з ознайомлення курсантів з естетичними й культурними цінностями, створення необхідних умов для реалізації їніх творчих здібностей і навичок, із залучення їх до активної наукової, громадської й культурно-масової діяльності і, передусім, навчання англійської мови професійного спрямування.

На сучасному етапі курсанти мають змогу прослуховувати запропоновані викладачем англомовні радіопередачі, навчальні аудіозаписи, переглядати телепередачі, фільми. У цьому разі навчальний ефект забезпечується підвищенням мотивації, пов'язаної з інформативністю й сучасністю радіоповідомлень, телепередач, фільмів і збільшенням практики в аудіюванні англійською мовою професійного спрямування. Крім того, курсанти часто мають змогу самостійно обирати аудіотексти, передачі, фільми тощо для оволодіння англомовним аудіюванням.

Оволодіння курсантами пенітенціарної служби англомовним аудіюванням $\epsilon$ вагомим, оскільки цей вид іншомовної мовленнєвої діяльності є складним для оволодіння, зумовленим значними суб'єктивними й об'єктивними труднощами.

Ключовими психологічними механізмами аудіювання є механізм слухового сприйняття, осмислення, оперативної й довготривалої пам'яті, ймовірного прогнозування, внутрішнього промовляння (Ветохов, 2003; Ніколаєва, 2009, с. 126). Аудіювання вимагає активної й систематичної роботи курсантів для досягнення позитивних результатів. Аудіотексти юридичної галузі придатні саме для самостійного позааудиторного опрацювання через недостатність часу на аудиторних заняттях і наявність технічної, зокрема комп’ютерної, техніки.

Аналіз останніх досліджень і публікацій. Вагомим внеском у теоретичне й практичне обгрунтування методики навчання аудіювання є праці О.Б. Бігич (2013, сс. 280-296; 2016, сc. 181-190, 306-316; 2011, сс. 175-189), зокрема методики формування у студентів мовних і немовних спеціальностей іншомовної компетенції / компетентності в аудіюванні. Проблемою добору навчального матеріалу для оволодіння компетентністю в аудіюванні займалися такі вчені-методисти, як Н.І. Бичкова, О.В. Єлухіна, Н.Є. Жеренко, І.П. Задорожна, С.Л. Захарова, Л.І. Іванова, О.В. Кміть, О.Б. Метьолкіна, О.В. Носоновіч, І.С. Онісіна, Н.Р. Петранговська, I.I. Халєєва, А.І. Черкашина, В.В. Черниш, Л.В. Шевкопляс, Л.В. Ягеніч, Ur P. Underwood та ін. Методисти детально виокремлювали принципи й критерії добору різних текстів для навчання аудіювання для різних типів закладів середньої й вищої освіти. Були досліджені критерії добору навчального матеріалу для формування компетентності в аудіюванні майбутніх учителів у процесі самостійної роботи (Шевкопляс Л.В.), аудіотекстів з національними й регіональними типами вимови (Мацнєва О.А.), теленовин (Вікович Р.І.), текстів-інтерв'ю (Литвін І.М.), професійно спрямованих повідомлень (Бочкарьова О.Ю.), драматичних творів (Сиваченко О.О.); була вибудована багаторівнева модель навчання аудіювання (Щукіна І.В), досліджена організація само- й взаємоконтролю рівня сформованості компетентності в аудіюванні (Крапчатова Я.А.), аудіювання з письмовою фіксацією суттєвої інформації (Колєснікова К.О.).

Однак питання оволодіння майбутніми фахівцями пенітенціарної служби англомовним аудіюванням наразі, зокрема проблема добору англомовного навчального матеріалу, залишається невирішеним.

Мета статті - обгрунтувати принципи добору дидактичного матеріалу для навчання англомовного аудіювання майбутніх фахівців пенітенціарної служби, зокрема курсантів першого курсу. 
Основні результати дослідження. Проблема добору навчальних матеріалів є однією 3 найскладніших у методиці навчання іноземних мов. Існує низка підходів до вирішення цієї проблеми: комунікативний, функціональний, ситуативно-функціональний, статистикопрагматичний тощо.

У контексті нашого дослідження ми обираємо навчальний матеріал на засадах професійно орієнтованого та ситуативно-функиіонального підходів до навчання іншомовного аудіювання.

Професійно орієнтований підхід передбачає врахування майбутньої професії й інтересів курсантів пенітенціарної служби під час навчання їх англомовного аудіювання. Згідно 3 дослідженням О.Б. Бігич (2018, сс. 13-14), професійно орієнтований підхід конкретизується в низці його різновидів:

- інтегроване навчання предметного змісту й мови (Content Language Integrative Learning CLIL) - зміщення акценту з виокремленого навчання іноземної мови для професійного спілкування на ії інтегрування з вивченням спеціальних дисциплін (О.Б. Тарнопольский, 3.М. Корнева, 2013);

- занурення - навчання через зміст (3.М. Корнева, 2006);

- комбіноване / змішане навчання (blended learning) - поєднання традиційної аудиторної роботи студентів з іноземної мови з їхньою позааудиторною роботою (О.Б. Тарнопольский, 3.М. Корнева, 2013);

- конструктивістсько комбіноване навчання - застосування викладачем іноземної мови експерієнціальних видів навчання (О.Б. Тарнопольский, 3.М. Корнева, 2013);

- інтегрований пiдxid (С.А. Коновальчук, 2017; І.Ю. Литвиненко, 2015; С.Я. Маслова, 2016 та ін.).

Суть ситуативно-функціонального підходу полягає в тому, що, грунтуючись на певних вихідних принципах $\mathrm{i}$ / чи критеріях, добирається навчальний матеріал, засвоєння якого забезпечить іншомовне спілкування тих, хто навчається, у типових комунікативних ситуаціях. Дібраний навчальний матеріал має системно-модельний характер і містить модель мовної, мовленнєвої і невербальної систем, використовуваних носіями мови.

У процесі добору дидактичних матеріалів для навчання англомовного аудіювання ми враховуємо такі принципи: тематичності; посильності й доступності; необхідності й достатності; вживаності; системності й послідовності; відповідності комунікативним потребам курсантів, їхньому інтелектуальному рівню й інтересам; пізнавальної, соціокультурної й професійно-практичної цінностей; автентичності.

Згідно з принципом тематичності відповідно до програми з англійської мови курсанти першого курсу пенітенціарної служби мають опанувати такі теми:

The profession of a lawyer.

The Constitution of Ukraine (state, national symbols, state power).

The Constitution of Ukraine (President, Parliament, Cabinet of Ministers).

The United Kingdom of Great Britain and Northern Ireland» (geography).

The Constitution of Ukraine.

The judicial system of Ukraine.

The United Kingdom of Great Britain and Northern Ireland (state power).

English system of law.

Classification of crimes.

Punishment.

Development of the prison system in Europe (prison, houses of correction).

Present Day penal institutions.

Принцип посильності й доступності передбачає, що дібраний навчальний матеріал має відповідати рівню знань, навичок і вмінь курсантів першого курсу. Збільшення обсягу 
навчального матеріалу, що має засвоюватися у відведений навчальною програмою проміжок часу, або складність його звучання негативно впливає на його засвоєння. Так, сприйняття мовлення на слух супроводжується подоланням труднощів, спричинених переважно трьома факторами: індивідуально-психологічними особливостями слухача, мовними особливостями мовленнєвого повідомлення й умовами сприйняття. Успішність аудіювання залежить від рівня розвитку у курсанта мовленнєвого слуху, слухової пам'яті, наявності уваги й інтересу, мотивації, загальних інтелектуальних передумов, іншомовних знань, навичок і вмінь тощо.

Отже, для навчання курсантів першого курсу слід враховувати їхні уміння слухати й швидко реагувати на сигнали усного мовлення (логічні наголоси, паузи, риторичні запитання, фрази зв’язку тощо), уміння переключатися з однієї розумової операції на іншу, схоплювати тему повідомлення тощо.

Згідно з дослідженнями Л. В. Туркіної, на молодших курсах механізм внутрішнього промовляння у курсантів ще не сформований на належному рівні й тому потребує значної уваги. Авторка рекомендує використовувати невеликі за обсягом тексти (200-300 друкованих знаків), побудовані загалом на знайомому курсантам матеріалі й пред'явлені зі швидкістю 200 складів / хвилину (Туркина, 1996, с. 79-80).

3 огляду на індивідуальні труднощі курсантів, особливо важливо розвивати механізми аудіювання у першокурсників через низький рівень сформованості їхньої аудитивної компетентності. Тому для курсантів першого курсу доцільно добирати навчальний матеріал насамперед для формування механізмів аудіювання.

Під час добору аудіотекстів потрібно також враховувати особливості мовного оформлення англомовного повідомлення, його смисл, обсяг, умови сприйняття, особливості джерел мовлення, види мовлення.

Унаслідок проведеного нами пробного навчання курсантів першого курсу було виявлено недостатній рівень сформованості аудитивної компетентності в більшості курсантів. Наприклад, під час опанування теми «Development of Prison System in Europe» курсантам було запропоновано прослухати тексти «Development of the Prison system» (39 нових лексичних одиниць) $\mathrm{i}$ «The Tower of London» (17 нових лексичних одиниць). Особливо важким виявилося завдання на перевірку розуміння деталей аудіотекстів. Загалом складність викликали перенасиченість назв, тривалість звучання (5-7 хвилин), фахова лексика, незнайомі граматичні звороти, надмірна кількість слів у реченні (до 36-38 слів) (див. рис.1).

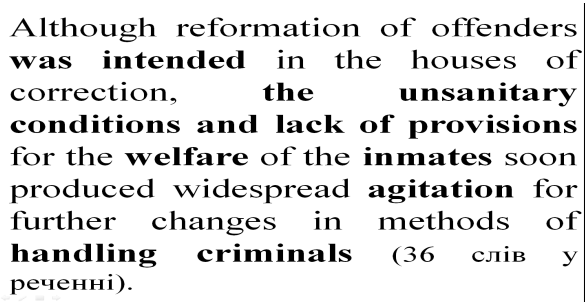

Рис. 1. Приклад складності речення аудіотексту

"Development of the Prison system"

Складність аудіотексту «The Tower of London» викликала перенасиченість історичними даними: Crown Jewels, the Middle Ages, Sir Thomas More (1535); the second wife of Henry VIII, Anne Boleyn (1536), Princess Elizabeth (later Elizabeth I, Mary I, Guy Fawkes (1606), Sir Walter Raleigh (1618) тощо (рис. 2). 


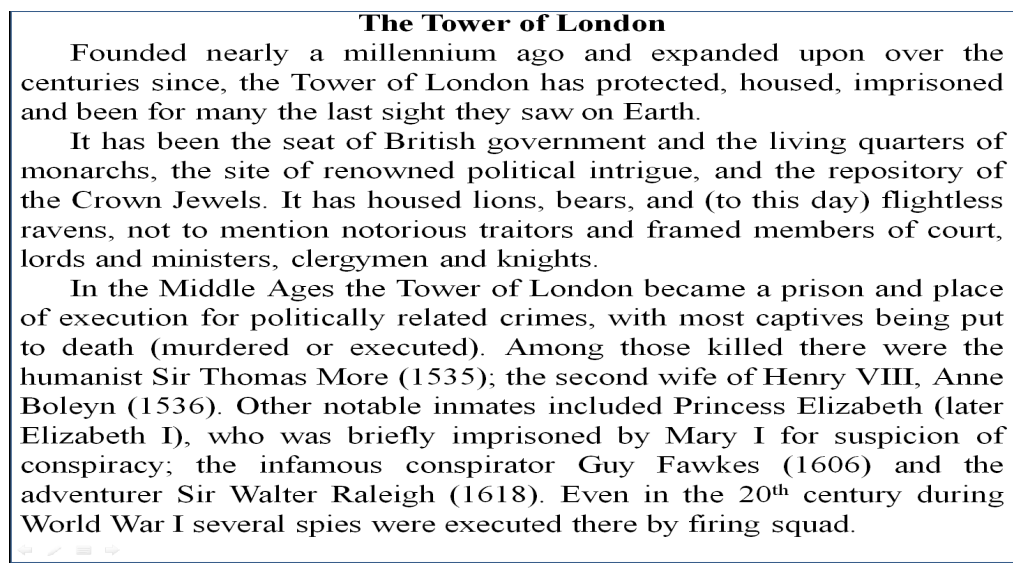

Рис. 2. Уривок тексту “The Tower of London”

Отже, вважаємо, що під час добору аудіотекстів, на першому курсі необхідно пред’являти тексти на вже опрацьованому на аудиторному занятті мовному матеріалі, допускаючи не більше 3-5-ти\% нової лексики; 8 лексичних одиниць у фразі, 10-12 слів у реченні; 7-8 прецизійних лексичних одиниць, які містять власні назви, географічні й історичні дані, назви національних реалій тощо; до 2-3-х хвилин звучання.

Щоб уникати труднощів, пов'язаних зі смисловим змістом аудіоповідомлення, необхідно добирати посильні, цікаві й змістовні для курсантів аудіотексти.

На першому курсі курсантів потрібно долучати до активного й зосередженого аудіювання. Поступово тривалість звучання треба збільшувати, практикуючи самостійне слухання аудіотекстів до 10-ти хвилин. Крім того, під час добору навчального матеріалу можна пропонувати курсантам для самостійного перегляду художні відеокліпи, в яких поєднання аудіо- й відеоряду певною мірою компенсує значну тривалість звучання. Також варто пропонувати курсантам переглядати уривки з фільмів із субтитрами.

Принцип вживаності, тобто частотності й поширеності, забезпечує можливість добору мовних і мовленнєвих явищ, видів усних текстів (монологів і діалогів) тощо, оскільки професійне спілкування службовців пенітенціарної служби має відносно обмежений перелік ситуацій, стандартизовану структуру текстів.

Згідно з принципом системності й послідовності передбачається, що дібраний навчальний матеріал має системний характер, його складники доповнюють один одного й створюють певну цілісність. Застосування необхідних для професійного англомовного спілкування мовних і мовленнєвих засобів здійснюється послідовно, їх засвоєння й опрацювання аудіой відео-засобами відбувається поступово й циклічно.

Принцип відповідності комунікативним потребам курсантів, їхньому інтелектуальному рівню й інтересам. Задоволення комунікативних й інтелектуальних потреб і відповідність інтересам курсантів, зокрема професійним, сприяють ефективності навчальної діяльності, оскільки врахування потреб особистості, які мотивують їхню діяльність, викликають у них позитивні емоції, що впливають на якість навчальної діяльності. Для формування й підтримування у курсантів інтересу до навчання аудіювання ми створюємо певні труднощі, проблемні ситуації, які наочно демонструють їм потребу в отриманні нових знань або застосуванні вже наявних у новій ситуації спілкування англійською мовою.

Відповідно до принципу пізнавальної, соціокультурної й професійно-практичної иінностей доцільно добирати навчальні матеріали, що демонструють актуальність проблем професійного 
спілкування, культури спілкування працівників пенітенціарної служби у певних ситуаціях в англомовних країнах, їхню поведінку тощо. Згідно з цим принципом добір навчального матеріалу враховує такі вимоги: добирати різні функціональні типи аудіотекстів, невеликих за обсягом і доступних для сприйняття курсантом; добирати аудіоматеріали відповідно до їхнього ціннісного смислу й значення; добирати інформацію про пенітенціарні установи країн англійської мови з урахуванням культурної різноманітності, демонструючи відмінності (у життєвих і ціннісних орієнтирах) різних представників тощо.

Добір навчального матеріалу за принципом соціокультурного потенціалу дає змогу надати національно-специфічну інформацію, закріпити соціокультурні знання, які отримали курсанти під час вивчення англійської мови в академії. Необхідно також, щоб цей навчальний матеріал викликав у курсантів бажання отримати нові знання про побут, традиції і звичаї, тюрми, життя ув'язнених в англомовних країнах тощо.

Принцип автентичності передбачає добір і використання в навчанні аудіювання автентичних навчальних матеріалів, оскільки вони наповнені національно-культурним змістом і відображають специфіку англомовних країн, англійської мови й культури, автентичність поведінки службовців пенітенціарної служби, в'язнів, кримінальних осіб. Автентичність навчального матеріалу передбачає охоплення тем і ситуацій та виконання вправ і завдань, які відповідають професійній сфері спілкування курсантів пенітенціарної служби. Автентичність включає текст сценарію, параметр мовлення й невербальний компонент.

Щодо джерел мовлення, то краще використовувати навчальні фільми, навчальні аудіозаписи, радіоновини тощо. Вважаємо за необхідне добирати навчальні фільми, наприклад «Private detective Jack Stark», де вжито відповідні професійні лексичні одиниці й граматичні структури і де аудіоряд поєднується з відеорядом; використовувати зорові опори, зокрема жести, зверненість мовлення, міміку тощо.

Водночас діалогічне й монологічне мовлення має презентуватись в оптимальному для курсантів темпі. Вони повинні мати змогу прослуховувати самостійно різні типи й види монологічних і діалогічних аудіотекстів, починаючи з першого курсу.

Висновки. Таким чином, ми добираємо дидактичний матеріал для навчання англомовного аудіювання курсантів першого курсу - майбутніх фахівців пенітенціарної служби на засадах професійно орієнтованого й ситуативно-функціонального підходів, враховуючи принципи тематичності; посильності й доступності; необхідності й достатності; вживаності; системності й послідовності; відповідності комунікативним потребам курсантів, їхньому інтелектуальному рівню й інтересам; пізнавальної, соціокультурної й професійно-практичної цінностей; автентичності.

Перспективи подальших розвідок. Виділені й описані принципи дають можливість докладно розглянути проблему добору навчальних текстів для навчання англомовного аудіювання курсантів пенітенціарної служби, а саме виокремити критерії добору навчальних текстів. У наступній науковій розвідці обгрунтуємо ці критерії.

\section{ЛІТЕРАТУРА}

Бігич, О. Б., Бориско, Н. Ф., Борецька, Г. Е., Гапонова, С. В., Майєр, Н. В., Ніколаєва, С. Ю., ... Шукліна, С. І. (2013). Методика навчання іноземних мов і культур: теорія і практика. Київ, Україна: Ленвіт.

Бігич, О. Б. (2011). Методика формування міжккультурної іниомовної комунікативної компетениї: Курс лекиій (схеми і таблииі). Київ, Україна: Ленвіт.

Бігич, О. Б. (2018). Професійно орієнтований підхід до навчання іноземної мови як непрофільної дисиипліни. Іншомовна підготовка прачівників правоохоронних органів і сектору безпеки: матеріали міжнародної науково-практичної конферениії. Київ: НАПУ. 
Ветохов, А. М. (2003). Пути повышения результативности обучения аудированию иноязычной речи в школе. Іноземні мови, 2, 7-9.

Бігич, О. Б., Бориско, Н. Ф., Борецька, Г. Е., Кузьменко, Ю.В., Майєр, Н. В., Ніколаєва, С. Ю., ... Шерстюк, О. М. (2016). Практикум з методики навчання іноземних мов і культур у загальноосвітніх навчальних закладах: англійська мова, німецька мова, франиузька мова, іспанська мова. Ірпінь, Україна: Романенко Л.Л.

Туркина, Л. В. (1996). Тестирование как один из приемов контроля навыков аудирования франиузской речи на начальном этапе обучения в вузе. (Кандидатская диссертация). Московский государственный педагогический институт. Москва, Российская Федерация.

\section{REFERENCES}

Bigych, O. B., Borisko, N. F., Borecka, G. E., Gaponova, S. V., Majyer, N. V., Nikolayeva, S. Yu., ... Shuklina, S. I. (2013). Metodika navchannya inozemnih mov i kultur: teoriya i praktika. Kyiv, Ukrayina: Lenvit.

Bigych, O. B. (2011). Metodika formuvannya mizhkulturnoyi inshomovnoyi komunikativnoyi kompetenciyi: Kurs lekcij (shemi i tablici). Kyiv, Ukrayina: Lenvit.

Bigych, O. B. (2018). Profesijno oriyentovanij pidhid do navchannya inozemnoyi movi yak neprofilnoyi disciplini. Inshomovna pidgotovka pracivnikiv pravoohoronnih organiv i sektoru bezpeki: materiali mizhnarodnoyi naukovo-praktichnoyi konferenciyi. Kyiv: NAPU.

Bigych, O. B., Borisko, N. F., Borecka, G. E., Kuzmenko, Yu.V., Majyer, N. V., Nikolayeva, S. Yu., ... Sherstyuk, O. M. (2016). Praktikum z metodiki navchannya inozemnih mov i kultur u zagalnoosvitnih navchalnih zakladah: anglijska mova, nimecka mova, francuzka mova, ispanska mova. Irpin, Ukrayina: Romanenko L.L.

Vetohov, A. M. (2003). Puti povysheniya rezul'tativnosti obucheniya audirovaniyu inoyazychnoj rechi $\mathrm{v}$ shkole. Inozemni movi, 2, 7-9.

Turkina, L. V. (1996). Testirovanie kak odin iz priemov kontrolya navykov audirovaniya francuzskoj rechi na nachal'nom etape obucheniya $\mathrm{v}$ vuze. (Kandidatskaya dissertaciya). Moskovskij gosudarstvennyj pedagogicheskij institut. Moskva, Rossijskaya Federaciya. 